\title{
Maximizing the Implementation of Scientific Approach in History Lessons Through Student-Centered Learning Model
}

\author{
Novika Ratnasari ${ }^{{ }^{1}}$, Kurniawati $^{2}$, Abdul Syukur ${ }^{3}$
}

${ }^{1}$ Program Pascasarjana Universitas Negeri Jakarta, Indonesia

A R T I C L E I N F O

Article history:

Received 4 July 2020

Received in revised

Form 15 July 2020

Accepted 25 July 2020

Available online 30

August 2020

Keywords:

Scientific Approach,

History, Curriculum 2013

\section{A B S T R A C T}

Curriculum changes and developments occur along with the development of educational theory and technological developments. These changes aim to improve the quality of education of Indonesia's human resources. The 2013 curriculum emphasizes the learning process using a scientific approach. The purpose of this study was to analyze the scientific approach in the 2013 curriculum in the implementation of history learning. The type of research used was a qualitative approach. This research was conducted at SMA Negeri 1 Babat Toman Musi Banyuasin. In this study, data were collected using observation, interviews, and document study method. Descriptive data analysis was used in this study. The results of this study indicate that the implementation of history learning in 2013 curriculum that uses a scientific approach through the Student-Centered Learning model and authentic assessment with $5 \mathrm{M}$ (observing, asking questions, collecting data, associating, communicating) maximize learning by following the 2013 curriculum development. This study as a reference material to maximize other subject in accordance with 2013 curriculum development.

\section{Introduction}

One of the education components that plays an important role in education progress is the teacher. What teachers can do is to carry out learning activities as well as possible with teaching techniques that make students active, motivated to take part in the learning process and be able to increase student curiosity so that learning objectives can be achieved (Oemar, 2011; Sanjaya, 2006; Suprihatin, 2015). The learning objectives are following those mandated in 2013 Curriculum. The learning process in 2013 curriculum emphasizes the use of a scientific approach.

The scientific approach is not new in education. The scientific approach is one of the priorities carried out by Kurikulum 2013 (Sudarsana, 2018; Susilana \& Heli, 2014; Sutarto, 2013). The scientific approach is a scientific activity to observe, asking questions, collecting information, associate, and communicate (Hosnan, 2016; Permatasari, 2014). In 2013 Curriculum, students are not only assessed on the final activity, but also in the learning process. Not only in the knowledge aspect, but also in the aspects of skills and attitudes, both social and spiritual attitudes. In line with this, learning activities in 2013 Curriculum directed to empower all students' potential so they can have the expected competencies to grow and develop attitudes, knowledge, and skills (Hosnan, 2016; Mulyasa, 2014).

The learning process with a scientific approach is designed in such a way that students can actively build concepts, laws or principles through stages, observing (to identify or find problems), formulate problems, propose or formulate hypotheses, collecting data with various techniques, analyzing data , drawing conclusions and communicate the concepts, laws or principles that have been found (Elvianto et al., 2018; Hosnan, 2016).

Scientific approach learning applied to all subjects, one of them is history. History are one of the subjects that have a very important role to develop character and develop Indonesian people who have a sense of nationality and love for the country (Jumardi, 2017). Learning history serves to make students aware of the society development and to develop historical perspectives and awareness in discovering, understanding, and explaining national identity in the past, present, and future in changing the world 
(Horohiung, 2017). So that history learning must be packaged as well as possible so that the material can be conveyed properly and learning objectives can be achieved. The current learning conditions expect students to be able to formulate problems (by asking a lot of questions), not only solving problems by answering. The learning process expected to train students to think in making decisions instead of thinking by listening without action (Dewi, 2016).

Based on the results of observations and interviews with one of the teachers at SMA Negeri 1 Babat, the problems faced were almost same as the process of learning activities with the previous curriculum (KTSP Curriculum). From the initial interviews, it was shown that History and Indonesian history subjects were not effective in learning activities carried out by teachers and students. There are so many obstacles felt by teachers who teach in research locations, the lack of understanding, training, and information obtained makes the learning process less effective. The change in curriculum from KTSP to Kurikulum 2013 made teachers difficult to share lesson material.

Difficulties are also experienced by students when learning activities take place. In learning activities, students only receive material delivered by the teacher. However, according to Kurikulum 2013, the implementation of learning is to make students more active and creative in learning activities, either directly or indirectly. So that to overcome these problems, in learning implementation with 2013 Curriculum the scientific approach must be emphasized more. The scientific learning approach can be carried out properly, it can be applied through the application of a learning model. The learning model used is more innovative and make students active. One learning model that can make students active is the Student-Centered Learning model.

The learning approach with the Student-Centered Learning model, the teacher must be able to carry out his role properly, to be a teacher, motivator, facilitator, and innovator (Antika, 2014). The function of the SCL model, it can help teachers to change students behavior, help teachers to create an appropriate learning environment, create effective interactions between teachers and students during the learning process, help teachers to choose learning material so that the implementation of learning is following 2013 Curriculum, provide materials for teachers to develop interesting and effective learning materials and resources, and stimulating the development of educational innovations or new learning.

Several studies have been carried out related to the scientific approach. (Prasetyawati, 2016) stated that history teachers carry out the learning process through five stages of the scientific approach, observing, asking questions, collecting data, associating, and communicating so that learning is no longer teacher centered but student centered. Research conducted by (Elvianto et al., 2018) concluded that teachers in general have carried out learning assessments based on the scientific approach following 2013 Curriculum. This study aimed to analyze the implementation of scientific approach in history learning based on 2013 Curriculum.

\section{Methods}

The method used in this research is qualitative research methods. The research procedure used in this study refers to the research procedure by Creswell which includes six stages. The first stage is identifying the research problem, the second stage is reviewing the literature, the third stage is specified research objectives, the fourth stage is collecting data. The fifth stage is analyzing and interpreting the data, and the sixth stage is reporting and evaluating the research. The research process carried out by researchers was to arrange a research proposal and make preliminary observations while at the same time trying to obtain permission in two research locations. The next step is collecting data, processing data or analyzing data, preparing reports, and concluding. This process carried out to obtain research results objectively (Nazir, 1988; Sugiyono, 2011).

This research was conducted at SMA Negeri 1 Babat Toman Musi Banyuasin. The population included all members of the MGMP History at the school. Data sampling was carried out randomly using purposive and snowball techniques. In this case, the researcher acts as a key instrument in determine the sample according to the research needs.

The data collection techniques used were observation, interviews, and document review. Observations were made on the learning process in the classroom, Teacher's daily life. MGMP at school level and at the time of learning evaluation, the researcher also conducted a document review in the form of teacher planning review, teacher programs in Indonesian history and historical subjects and achievement of student learning score. To observe the attitudes, researchers conducted a documentary study of the teacher's attitude assessment journal.

The data analyzed with descriptive analysis which is inductive/qualitative in nature, and the results of qualitative research emphasize meaning rather than generalization. Data analysis was performed 
through triangulation. Triangulation is defined as a data analysis technique that tests the credibility of data from various data sources (Moleong, 2017).

\section{Result and Discussion}

History learning carried out at SMA Negeri 1 Babat Toman uses a scientific approach through the Student-Centered Learning model and authentic assessment can maximize learning activities following 2013 Curriculum. With this application, students will be interested and do not get bored during learning so that the results obtained are following Kurikulum 2013 and curriculum development can be optimal.

The SCL learning model used with a scientific approach, which previously focused on teachers (teacher-centered) into student-centered learning which is expected to encourage students to involved in knowledge, attitudes, and behavior. Through a learning process that involves students to be active, students get the opportunity and facilities to develop their knowledge so they will get deep understanding which can improve the quality of students. Through the application of student-centered learning, students are expected to be active, critical thinking, analyzing, and solve their problems.

The student-centered learning model (SCL) will impact students to have opportunity and facilities to develop their knowledge so that they will gain a deep understanding which can improve the quality of the students themselves (Unin \& Bearing, 2016; Uslan \& Nuriyah, 2018). The SCL learning model is a learning process with a scientific approach, previously focused on the teacher (teacher-centered) to become student-centered learning, which expected to encourage students to involved in knowledge, attitudes, and behavior development.

Learning process involves students actively, students get opportunity and facility to build their knowledge so they will gain a deep understanding which can improve the quality of students. Through the application of student-centered learning, students are expected to be active, have critical thinking, analyzing, and solve their problems (Sadikin, 2017). It can be seen from the change in learning principles or $21^{\text {st }}$ Century Learning Paradigm according to the Competency Standards for Graduates and the content standards are presented in table 1.

Table 1. 21st Century Learning according with Standard Competency dan Standard Content

\begin{tabular}{|c|c|}
\hline Old learning priciples & Current learning principles \\
\hline Students are notified & Learners find out \\
\hline The teacher as the only source of learning & Students learn based on various learning resources \\
\hline Students learn with a textual approach & $\begin{array}{l}\text { Students learn by strengthening the scientific } \\
\text { approach }\end{array}$ \\
\hline sed learning activities & Competency-based learning activities \\
\hline Partial based learning activities & Integrated learning activities \\
\hline Learning that emphasizes single answers & Learning with multidimensional truthful answers \\
\hline Learning activities are verbalism / mere words & Learning activities are applicative / applied \\
\hline $\begin{array}{l}\text { Less prioritizing the culture and empowerment of } \\
\text { students as learners }\end{array}$ & $\begin{array}{l}\text { Learning by prioritizing the culture and } \\
\text { empowerment of students as lifelong learners }\end{array}$ \\
\hline $\begin{array}{l}\text { Lack of improvement and balance between physical } \\
\text { skills (hard skills) and mental skills (soft skills) }\end{array}$ & $\begin{array}{l}\text { Improve the balance between physical skills (hard } \\
\text { skills) and mental skills (soft skills) }\end{array}$ \\
\hline ing activities only take place at school & $\begin{array}{l}\text { Learning activities can take place at home, at } \\
\text { school, and in the community. }\end{array}$ \\
\hline $\begin{array}{l}\text { Lack of application of the principle of } \\
\text { empowerment / empowerment of communication } \\
\text { in learning activities }\end{array}$ & $\begin{array}{l}\text { Learning activities by applying the principle of } \\
\text { empowerment / empowerment that anyone is a } \\
\text { teacher, who is a student, and where is the class }\end{array}$ \\
\hline $\begin{array}{l}\text { The lack of use of information and communication } \\
\text { technology (ICT) to increase the efficiency and } \\
\text { effectiveness of learning }\end{array}$ & $\begin{array}{l}\text { Utilization of information and communication } \\
\text { technology (ICT) to increase the efficiency and } \\
\text { effectiveness of learning optimally }\end{array}$ \\
\hline $\begin{array}{l}\text { Lack of application of exemplary values, } \\
\text { willingness, and creativity development of students }\end{array}$ & $\begin{array}{l}\text { Learning activities with the application of values } \\
\text { through exemplary giving (ing ngarso sung tulodo), }\end{array}$ \\
\hline in the learning process & $\begin{array}{l}\text { building will (ing madyo mangun karso), } \\
\text { developing student creativity in the learning } \\
\text { process (tut wuri handayani) }\end{array}$ \\
\hline $\begin{array}{l}\text { Lack of recognition of the individual differences } \\
\text { and cultural backgrounds of learners }\end{array}$ & $\begin{array}{l}\text { Recognition of the individual differences and } \\
\text { cultural backgrounds of students }\end{array}$ \\
\hline
\end{tabular}


Teaching with the SCL model, first, the teacher needs to know the challenges of individual needs and interests, and to plan, implement and evaluate teaching that will cover the needs and interests of students (Taçman \& Menteş, 2010). This is in line with (Judi \& Sahari, 2013) which stated that SCL provides an environment that makes students play a more active role in acquiring knowledge by accessing the main materials and resources in the learning process.

The characteristic that this learning model is student-centered, it means that the educational environment forms a system in such a way that students want to play an active role in exploring science along with their increasing awareness of the need for this knowledge (Siradj, 2014).. The SCL learning model can help students to gain experiences in learning because this model places students at the center of the learning process by combining various activitiy such as discussions, field observations, making concept maps of problems and their solutions, presentations, and reflections (Harahap et al., 2020).

The scientific approach through the Student-Centered Learning learning model can maximize the application of 2013 Curriculum. This statement supported by (Prasetyawati, 2016) which states that through a scientific approach the aspects of strengthening attitudes, skills, and integrated knowledge to productive, affective, innovative, and creative. Learning that used a scientific approach is more effective than traditional learning, and learning is more learner-centered.

Assessment in 2013 Curriculum used authentic assessment. An authentic assessment is an assessment that assesses all aspects of students during learning activities. An authentic assessment assesses the cognitive, psychomotor, and affective aspects of students who are assessed not only at the end of learning (Wildan, 2017). So that the scientific approach that is integrated with authentic assessment is very suitable for Kurikulum 2013 development.

Curriculum development in 2013 also emphasizes perfect mindset, strengthening curriculum governance, deepening and expanding material, strengthening the learning process, and adjusting the learning load to ensure a match between what is desired and what is produced (Ulhaq et al., 2017). The results that support this research were conducted by (Permatasari, 2014) which showed that at SMA Negeri 2 Batang in teaching history the teacher had tried to apply a scientific approach. In history learning, students are expected to have critical thinking from the object they see, and students' curiosity begins to increase. This research shows that students are more courageous in expressing opinions in front of many people and other students can also learn from other people's opinions and respect each other's opinions so that learning for history subjects can run well.

Similar research results were also carried out by (Diani, 2016). Based on the results of the research and data management analysis t-test at a significant level $=0.05$, it was obtained that tcount $>$ ttable was 5.45415> 1.68107, meaning that H0 was accepted. Thus, learning physics using a scientific approach assisted by worksheets has more effect on students' physics learning outcomes compared to those who do not use a scientific approach.

Subsequent research was carried out by (Umar, 2016) which showed that the use of a scientific approach with project-based learning methods was very effective in chemistry learning activities, where the steps in this method could make learning activities more meaningful. The scientific approach with a project-based learning model will increase student attractiveness to chemistry subjects, develop students' attitudes, knowledge, and skills so that learning is expected to be productive, creative, innovative, and effective through strengthening attitudes, knowledge and skills integrated.

From the above discussion, it can be understood that the implementation of the scientific approach and authentic assessment in Kurikulum 2013 has positive impact on teachers and students. So, these findings are expected to provide additional insight for teachers and other researchers, and can make these findings a reference in the implementation of learning and implementation of further curriculum study research.

\section{Conclusion}

Based on the analysis of the results of research and discussion, it can be concluded that the development of historical learning with a scientific approach through Student-Centered Learning and authentic assessment at SMA Negeri 1 Babat Toman has a positive impact on teachers and students. Teaching and learning activities can run well according to what is expected from the 2013 Curriculum. The learning process goes well where students are more active to find information needed. Evaluation in history learning with a scientific approach carried out by history teachers at SMA Negeri 1 Babat Toman by following the stages in authentic assessment which includes cognitive, affective, and psychomotor domains which include learning outcomes in the form of observation sheets (nontest) and written test assessments. 


\section{References}

Antika, R. R. (2014). Proses Pembelajaran Berbasis Student Centered Learning (Studi Deskriptif di SMP Islam Baitul 'Izzah, Nganjuk). Jurnal Biokultur, 3(1), 251-265. http://www.journal.unair.ac.id/download-fullpapers-bk21a95d451ffull.pdf.

Dewi, P. S. (2016). Kemampuan Proses Sains Siswa Melalui Pendekatan Saintifik Dalam Pembelajaran IPA Terpadu Pada Tema Global Warming. Edusains, 8(1), 18-26. https://doi.org/10.15408/es.v8i1.1564

Diani, R. (2016). Pengaruh pendekatan saintifik berbantukan LKS terhadap hasil belajar fisika peserta didik Kelas XI SMA Perintis 1 Bandar Lampung. Jurnal Ilmiah Pendidikan Fisika Al-Biruni, 5(1), 8393. https://doi.org/10.24042/jpifalbiruni.v5i1.108

Elvianto, S., Nursaid, N., \& Zulfikarni, Z. (2018). Penerapan Pendekatan Saintifik Pada Aspek Penilaian Dalam Pembelajaran Teks Negosiasi Di Kelas X Smk Muhammadiyah 1 Padang. Jurnal Pendidikan Bahasa Indonesia, 7(1), 230-238. https://doi.org/10.24036/9566-019883

Harahap, N. A., Ummah, K., Rohanawati, A. N., \& Mardhatillah, S. R. (2020). Pengembangan model pembelajaran Student Center Learning (SCL) berbasis aktivitas pada mata kuliah Pendidikan Pancasila di Fakultas Hukum. Refleksi Pembelajaran Inovatif, 1(2). https://doi.org/https://doi.org/10.20885/rpi.vol1.iss2.art8

Horohiung, V. (2017). Pengaruh Strategi Pembelajaran dan Kemampuan Berpikir Kritis Terhadap Hasil Belajar Sejarah Siswa SMA Negeri 72 Jakarta. Jurnal Pendidikan Sejarah, 6(1), 1-10. 10.21009/JPS.061.01

Hosnan, M. (2016). Pendekatan Saintifik dan Kontekstual dalam Pembelajaran Abad 21. Ghalia Indonesia.

Judi, H. M., \& Sahari, N. (2013). Student Centered Learning in Statistics: Analysis of Systematic Review. Procedia-Social and Behavioral Sciences, 103, 844-851. https://doi.org/10.1016/j.sbspro.2013.10.406

Jumardi, J. (2017). Peranan Pelajaran Sejarah Dalam Pengembangan Karakter Siswa melalui Pembelajaran Berbasis Nilai Sejarah Lokal di SMA Negeri 65 Jakarta Barat. Jurnal Pendidikan Sejarah, 6(2), 70-80. https://doi.org/10.21009/JPS.062.08

Moleong, J. (2017). Metodologi Penelitian Kualitatif. Pt Remaja Rosdakarya.

Mulyasa, E. (2014). Pengembangan dan Implementasi Kurikulum 2013 (5th ed.). Pt Remaja Rosdakarya.

Nazir, M. (1988). Metode Penelitian. Ghalia Indonesia.

Oemar, H. (2011). Kurikulum dan Pembelajaran. Bumi Aksara.

Permatasari, E. A. (2014). Implementasi pendekatan saintifik dalam kurikulum 2013 pada pembelajaran sejarah. Indonesian Journal of History Education, 3(1). https://journal.unnes.ac.id/sju/index.php/ijhe/article/view/3884

Prasetyawati, P. (2016). Analisis Proses Pembelajaran Berbasis Student Centered Learning Dalam Pendekatan Saintifik Pada Mata Pelajaran Sejarah Di SMA Negeri Se Kota Palu. Katalogis, 4(10), 130-137. http://jurnal.untad.ac.id/jurnal/index.php/Katalogis/article/view/7010

Sadikin, M. (2017). Analisis Pembelajaran Sejarah dengan Pendekatan Saintifik pada Kurikulum 2013. Sosial Horizon: Jurnal Pendidikan Sosial, 4(2), 219-227. https://doi.org/10.31571/sosial.v4i2.660

Sanjaya, W. (2006). Strategi Pembelajaran: Berorientasi Standar Proses Pendidikan. Kencana Prenada Media Group.

Siradj, Y. (2014). Implementasi SCL (Student Centered Learning) Pada Pembelajaran Kuliah Jaringan Komputer (Studi Kasus: Politeknik Telkom). Parameter, 24(1), 100-112. https://doi.org/10.21009/parameter.241.02

Sudarsana, I. K. (2018). Optimalisasi Penggunaan Teknologi Dalam Implementasi Kurikulum Di Sekolah (Persepektif Teori Konstruktivisme). Cetta: Jurnal Ilmu Pendidikan, 1(1), 8-15. http://jayapanguspress.penerbit.org/index.php/cetta/article/view/41

Sugiyono. (2011). Metode Penelitian Kuantitatif, Kualitatif, dan R\&D. Alfabeta. 
Suprihatin, S. (2015). Upaya Guru Dalam Meningkatkan Motivasi Belajar Siswa. Jurnal Pendidikan Ekonomi UM Metro, 3(1), 73-82. https://doi.org/10.24127/ja.v3i1.144

Susilana, R., \& Heli, I. (2014). Pendekatan saintifik dalam implementasi kurikulum 2013 berdasarkan kajian teori psikologi belajar. Edutech, 13(2), 183-193. https://doi.org/10.17509/edutech.v13i2.3095

Sutarto. (2013). Kurikulum dan pembelajaran dalam Implementasi pada Kurikulum 2013. CV. Kemilau Ilmu Semesta.

Taçman, M., \& Menteș, R. (2010). A qualitative research on teacher's in the TRNC towards the situation on learning the usage of student centred education. Procedia - Social and Behavioral Sciences, 9, 20622068. https://doi.org/10.1016/j.sbspro.2010.12.447

Ulhaq, Z., Nuriah, T., \& Winarsih, M. (2017). Pembelajaran Sejarah Berbasis Kurikulum 2013 di SMA Kotamadya Jakarta Timur. Jurnal Pendidikan Sejarah.

Umar, M. A. (2016). Penerapan Pendekatan Saintifik dengan Menggunakan Metode Pembelajaran Berbasis Proyek (Project-Based Learning) pada Mata Pelajaran Kimia. Jambura Journal of Educational Chemistry, 11(2), 132-138.

Unin, N., \& Bearing, P. (2016). Brainstorming as a Way to Approach Student-centered Learning in the ESL Classroom. Procedia - Social and Behavioral Sciences, 224(15), 605-612. https://doi.org/10.1016/j.sbspro.2016.05.450

Uslan, U., \& Nuriyah, N. (2018). Model Student Centered Learning (SCL) di Sekolah Dasar (SD) yang Inovatif Terintegrasi Pembelajaran Terpadu. PENDAS MAHAKAM: Jurnal Pendidikan Dasar, 3(1), 63-67. https://jurnal.fkip-uwgm.ac.id/index.php/pendasmahakam/article/view/225

Wildan, W. (2017). Pelaksanaan Penilaian Autentik Aspek Pengetahuan, Sikap dan Keterampilan di Sekolah atau Madrasah. Jurnal Tatsqif, 15(2), 131-153. https://doi.org/10.20414/jtq.v15i2.3 